\title{
Közösségi közlekedés intézményes piacra lépési szabályainak hazai lehetôségei
}

\author{
A hat regionális (autóbuszos) közlekedési központ és a Volánbusz Zrt. \\ közszolgáltatási szerződése 2019. december 31-én lejár. Az időpont kö- \\ zelsége és a feladatok nagysága különösen fontossá és aktuálissá teszi \\ a témával való részletes foglalkozást.
}

DOI 10.24228/KTSZ.2019.4.1

\section{Dr. Szeri István - Ács Balázs \\ KTI Közlekedéstudományi Intézet Nonprofit Kft. \\ e-mail: szeri.istvan@kti.hu, acs@kti.hu}

\section{BEVEZETÉS}

Napjainkban egyértelmű közlekedéspolitikai szándék a helyközi közösségi közlekedési alágazatok (vasúti, autóbusz), valamint a helyi és helyközi (országos, elővárosi és regionális) közlekedési rendszerek szolgáltatási, intézményrendszeri és ellátási összehangolása, amelyet ma már a hazai jogszabályi környezet is támogat.

Az alapvető célok mind a helyi, mind a helyközi közlekedésben rögzítettek olyan dokumentumokban, mint a Nemzeti Közlekedési Infrastruktúra-fejlesztési Stratégia [5], vagy azok a hasonló stratégiai anyagok, amelyek korábban, különösen 2010-től készültek. Az 1370/2007-es EK rendelet, a közösségi közlekedés alapdokumentumának figyelembevételével a személyszállítási szolgáltatásokról szóló hazai speciális szabályozás (2012. évi XLI. törvény, továbbiakban Sztv.) szintén a fenti célokat szolgálja.

Ma már nem lehet csak közösségi közlekedési feladatellátásban gondolkodni, hanem átfogóbb módon, mobilitási ajánlatok létrehozását, erősítését kell feladatul tűzni. A magas színvonalú közforgalmú közlekedéshez elengedhetetlen az átgondolt infrastrukturális felzárkóztatás is, amely - többek között - a gyorsforgalmú utak fejlesztésével, vasúti pályák korszerüsítésével, intermodális csomópontokkal (IMCS) és intelligens megoldásokkal (ITS) valósítható meg. A 2020-ig szóló európai „Fehér Könyv - Útiterv” [6] program félúton jár az egységes európai közlekedési térség létrejöttéhez vezető folyamatban. Már abban a dokumentumban megállapításra került, hogy a közlekedési rendszerek reformját csak a nemzeti, regionális és helyi hatóságokkal koordinálva lehetséges végrehajtani, és a rendelkezésre álló erőforrások hatékony felhasználását ehhez fokozni kell. A 2030-ig szóló mobilitás koncepció már túlmutat az általános európai közlekedéspolitika hagyományos területein.

Ahhoz azonban, hogy hazánk is megfeleljen a 2030-ig felvázolt kihívásoknak, a jövőben az összes rendelkezésre álló közlekedési mód optimális hálózatba állítása, integrálása szükséges. Ebbe beletartozik az is, hogy a hagyományos közösségi közlekedési eszközrendszereken túl legális és szabályozott módon hozzáférhetővé kell tenni az ún. „alternatív" közlekedési módokat (pl. költségmegosztók) is. 


\section{A KÖZFORGALMÚ HELYKÖZI KÖZLEKEDÉS JELENTÖSÉGE}

A közlekedési megoldásoknak - nemzeti és nemzetközi szinten egyaránt - alkalmazkodniuk kell mind a jelentkező mobilitási igényekhez, mind a földrajzi régiók eltérő térbeli struktúrájához. A hazai személyszállítási szolgáltatásoknak - különösen a szolgáltatáshiányos aprófalvakban és zsáktelepüléseken még ma is infrastruktúrapótló szerepük van. Jellemzően a helyközi, autóbuszos, személyszállítási közszolgáltatás biztosítja a kisebb települések lakói számára a munkába és iskolába járás, a kereskedelmi és egészségügyi ellátórendszerhez való hozzáférés lehetőségét. Ennél fogva a közforgalmú, menetrend szerinti autóbusz-közlekedés általános érdekü szolgáltatásnak tekinthetö, amelyre nem lehet úgy tekinteni, mint egy piaci alapon müködő/ érdekű tevékenységre. Az egyedi követelményekhez illeszkedő, differenciált kiszolgálásra van szükség, amelyet eltérő cselekvési prioritások vezérelnek majd, különösen a megyeszékhelyek, járási központok és kisebb települések kapcsolatainak vonatkozásában.

A következetes intézkedések ma különösen fontosak. A szélessávú internet és a digitalizáció hazai látványos térnyerésével terjed az atipikus foglakoztatás (távmunka), illetve különösen a felsőoktatásban az atipikus tanulási formák (távoktatás) gyakorlata. Ez jelenheti a hivatásforgalmi utazások volumenének jelentős csökkenését, ugyanakkor egy növekedő gazdaságban a nem munkavégzéssel és tanulással összefüggő - pl. szabadidős - utazási igények növekedésére is fel kell készülni. A munkavégzéssel összefüggő utazási igényeket mindezen felül olyan színvonalon kell kiszolgálni, hogy a munkaerőpiac területén fennálló különbségek a nemzetgazdaság számára hasznos mértékben mérséklödjenek. A jövőben is követelmény marad, hogy a közforgalmú szolgáltatások igénybevétele vonzó legyen, valódi alternatívát jelentsen az egyéni közlekedéssel szemben, de ez elsősorban a nagyvárosokban és azok környékén kiemelten fontos, a sporadikus területeken már kevésbé. A nagyvárosias környezetben az egyéni motorizáció növekedési ütemének felgyorsulása magával hozza a közlekedéssel együtt járó externális költségek növekedését is, ezért ezt a folyamatot érdemes fékezni, és ehhez megfelelő eszköz a jó színvonalú és lefedettségü, elérhető tarifájú közforgalmú közlekedés.

A jövő közösségi közlekedésének fő kérdése, hogy miképpen lehet a közlekedési szolgáltatási rendszert az új kihívások okán minél inkább fenntarthatóvá tenni, mind gazdasági, mind müszaki téren. Utóbbi szempontból aktuális feladat, hogy fejleszteni kell az energiapolitikai követelményeknek megfelelően a jármüvek hajtásrendszerét a hazai közforgalmú közlekedési rendszerekben (hibrid és elektromos hajtás), ugyanakkor ki kell szolgálni a változó társadalmi és technológiai trendeknek megfelelő igényeket is (pl. igényvezérelt közlekedés), és erre jó lehetöséget jelent a digitalizáció. A kínálatnak tehát a lehető leginkább utasbarátnak kell lennie, jármü- és rendszerszinten is célkitüzéssé kell tenni az energiatakarékosság fokozását és a károsanyag-kibocsátás csökkentését. Társadalmilag kiegyensúlyozottá kell tenni az ismert (és ma még nem ismert) mobilitási formák optimális kölcsönhatását (gyaloglás, kerékpározás, tömegközlekedés, egyéni motorizáció, költségmegosztás, utasok általi autómegosztás), annak érdekében, hogy az egyéni igények szerint lehessen szolgáltatni, biztosítva ezzel a leggazdaságosabb mobilitási láncolatot a helyváltoztatásra kényszerített vagy önkéntes utasnak.

Ehhez alapvető követelmény a megbízható és gazdaságos teljesítményre orientált közlekedési szolgáltatás és infrastruktúra, a térben és időben leképzett közlekedési módok és ahhoz kapcsolt utasinformációs rendszer, a multi- és intermodális közlekedési infrastruktúrák (pl. intermodális csomópontok, pályaudvarok stb.) átlátható használata.

Egy országosan is működő közösségi közlekedés csak akkor müködhet megfelelően, ha azt regionálisan differenciált módon építik fel. A közösségi közlekedés hatékony ellátása erős társadalmi felelösség. Folyamatosan fejleszteni kell, biztonságossá és versenyképessé kell tenni az emberi és épített környezet érdekében, 


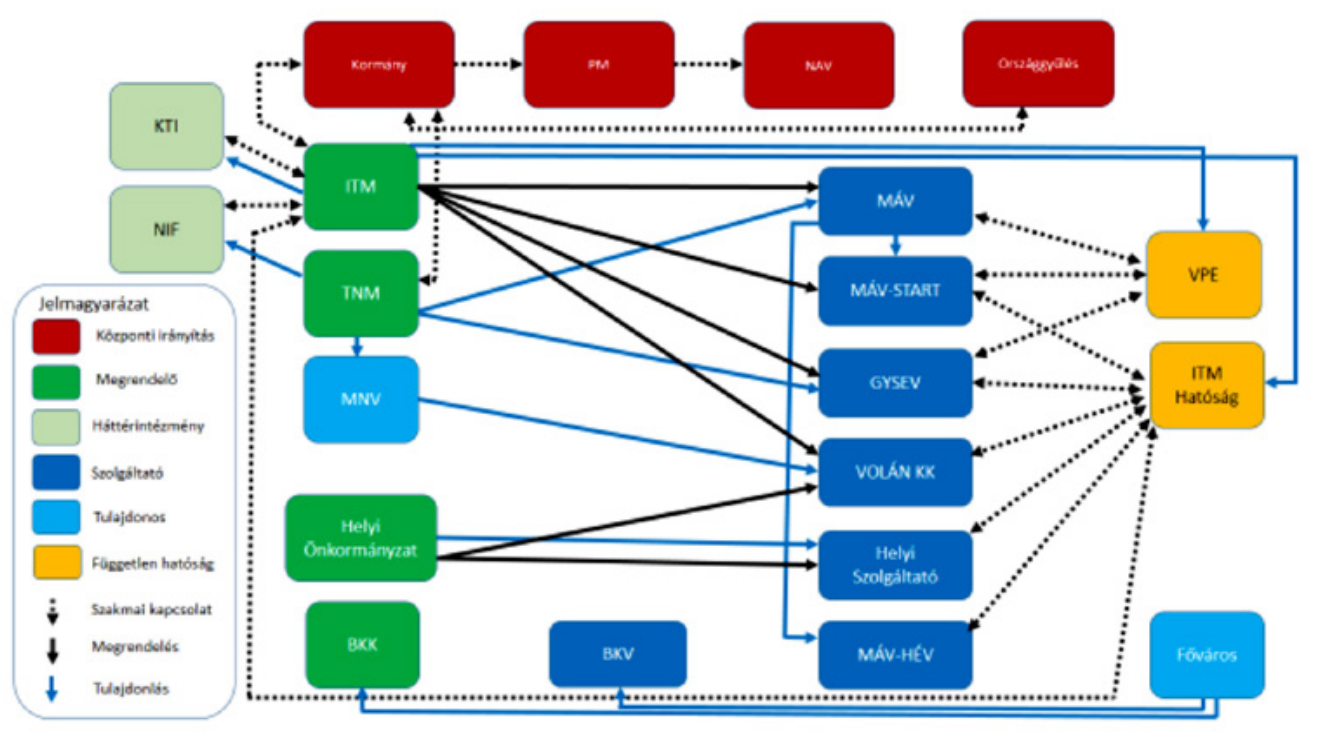

és - noha jelenleg állami szervezésű és finanszírozású szolgáltatásokról van szó - mindig figyelemmel kell lenni a területi adottságokra, prioritásokra, érdekhordozókra.

A hazai személyszállítási közszolgáltatás bonyolult funkció- és folyamatrendszerrel rendelkezik, amelyekből világosan látszik a szolgáltatás társadalmi fontossága és érzékenysége. Addig, amíg az ellátási felelősi rendszer kétpólusú (állam és önkormányzat), ezeknél a szervezeteknél közhatalmi funkcióikból eredően egyszerre jelennek meg a szabályozási, megrendelöi, finanszírozói, engedélyezési és felügyeleti hatáskörök. A létező jogi és technikai megoldások, mind a szolgáltatásfejlesztés, mind pedig az intézményfejlesztés területén mutatnak olyan típusú lehetőségeket, amelyek hazánkban is alkalmazhatók. Magyarország méretét és a közforgalmú közlekedéssel ellátott területek nagyságát is figyelembe véve a kétpólusú rendszer ellátási felelősi kompetenciák vonatkozásában megfelelőnek látszik, ám elgondolkodtató, hogy a szubszidiaritás elvén lehetne-e hárompólusúvá tenni? (Település, megye vagy régió, ill. az állam.) Amennyiben a jövőbeni szakmapolitika az integrációt he- lyezi előtérbe, annak kialakítása kifejezetten a jelenlegi hatóságok (állam vagy települési önkormányzatok) akaratán múlik.

Az integrált ellátási felelősség színterén csak az ellátási felelősök (megrendelők) kezdeményezhetik a feladathoz szükséges megrendelöi és operátori rendszer kialakítását (amelyhez piacra lépési szabályok is tartoznak), ehhez pedig mind az európai, mind pedig a hazai szabályozások megfelelő keretet nyújtanak. Így akár az integrált megrendelő szervezetek, akár azok szerződéses szövetsége elsősorban a szolgáltatások minőségi integrációját, így különösen a költségvetési és társadalmi költségek racionálisabb felhasználását szolgálhatják.

\section{A KÖZFORGALMÚ HELYKÖZI KÖZLEKEDÉS MISSZIÓJA, VÍZIÓJA}

Számos tanulmány, elemzés, fejlesztési elképzelés született arról, hogy miként lehetne a közösségi közlekedés rendszerét a mai kor követelményeinek megfelelően megreformálni, átalakítani. A 2018-ban megalakult állami ellátási felelős, az Innovációs és Technológiai 


\section{Közösségi közlekedés}

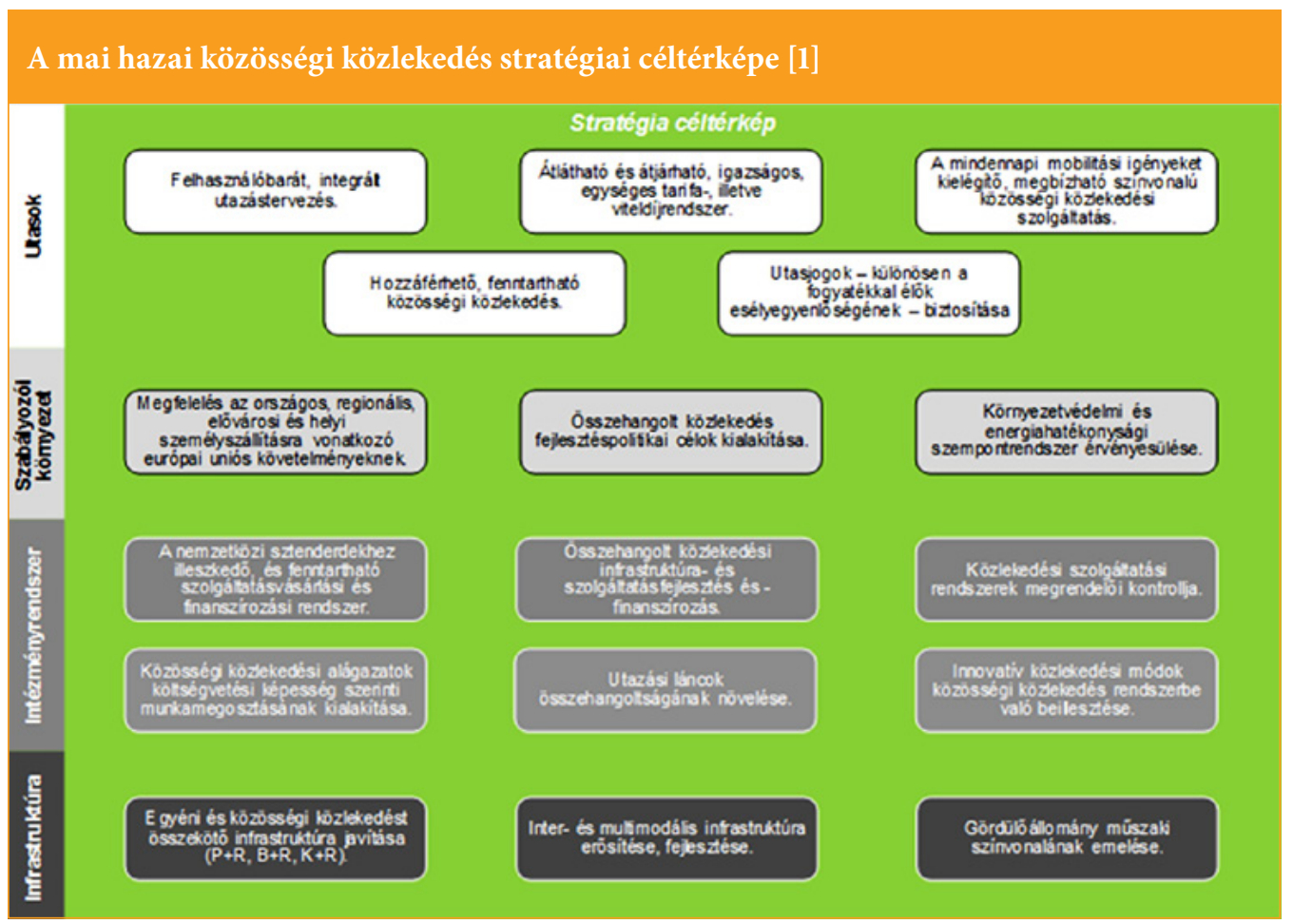

Minisztérium a közforgalmú közlekedésre vonatkozó víziót és missziót az alábbi öt érték mentén úgy határozta meg, hogy az „legyen

- utasbarát,

- innovatív,

- fenntartható,

- integrált,

- és rugalmas." [1]

„A közösségi közlekedési rendszer fö célja, hogy úgy teremtsen hozzáférhetőséget a korszerü, alternatív közlekedési módokhoz, hogy eközben lassítsa az egyéni mobilitás térnyerésének ütemét. A fenntarthatóság legföbb biztosítéka az alágazatok infrastrukturális- és szolgáltatásfejlesztésének integrált megközelítése és a szakmai és pénzügyi kontroll egyidejü biztosítása" [1].

Hazánkban ma még egy viszonylag jó területi és időbeli lefedettségü hálózat üzemel, az EU-28-ak között Magyarországon a legmagasabb a közforgalmú közlekedést választók aránya (modal share). Ezt a szintet célszerü lenne megőrizni, de ehhez a rendszer finan- szírozási forrásait folyamatosan bővíteni kell. Ám ha jövőben kevesebb forrásból kell működtetni a közösségi közlekedés rendszerét, az vélhetően színvonal-, utasszám- és bevételcsökkenéssel jár. Amennyiben a hazai közlekedéspolitika át tud lépni azokon a közpolitikai korlátokon, amelyek eddig determinálták, a jelenlegi finanszírozási helyzetben is lehet jobb színvonalú közlekedési rendszert fejleszteni, de fel kell tenni - és meg kell válaszolni - néhány kritikus kérdést. Például azt, hogy:

- érdemes-e a közforgalmú közlekedésnek minden szegmensben (előváros, regionális, országos) az egyéni közlekedéssel szemben versenyképesnek lennie?

Az elővárosi közlekedésben ez a cél aligha vitatható, de

- a sporadikus regionális környezetben elvárható-e, hogy a kritikusan alacsony igénybevétel ellenére is megfelelő sürüségü és magas minőségű közforgalmú, menetrend szerinti személyszállítás legyen biztosítva? 


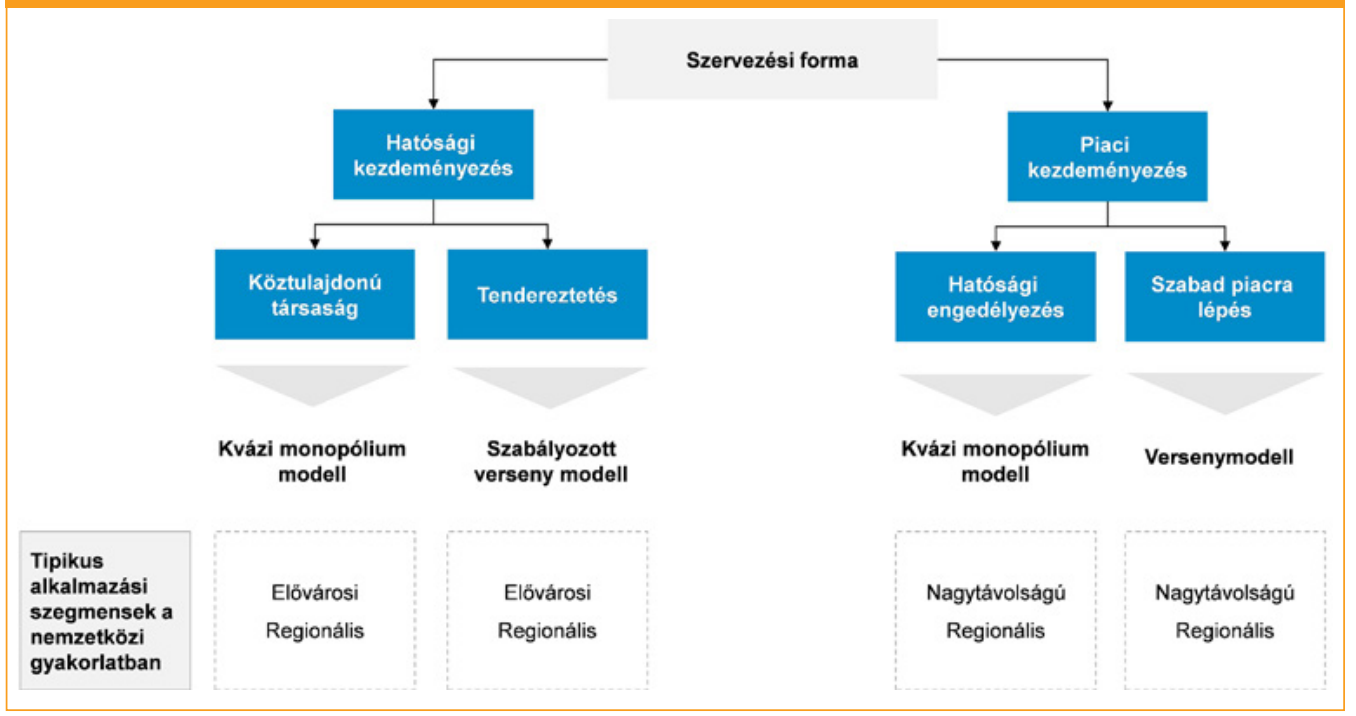

- Mennyire érdemes teret engedni az alternatív megoldásoknak, mint például a szabályozott körülmények között működő alternatív szolgáltatók, sharing economy alapú költségmegosztók?

Egy szolgáltatásrendszer négy dimenzió mentén fogalmazható meg:

- utasok,

- szabályozói környezet,

- intézményrendszer,

- infrastruktúra.

Társadalmi érdek, hogy létrejöjjön egy hosszú távon kiszámítható, ugyanakkor takarékos, a közlekedési igényeket folyamatosan követö közszolgáltatási struktúra. Amennyiben tartósan önkormányzati megrendelés alatt marad a helyi közlekedés, világos és egyértelmü együttműködés kell az állami ellátási felelős és az önkormányzati ellátási felelösök között. Ennek jogi megoldása létezik hazánkban, ugyanis a helyi és helyközi szolgáltatások integrációjára, elővárosi vonalakon nyújtott helyi személyszállítási szolgáltatások megrendelésére a Sztv. 5. \$ (3) bekezdésének a) és b) pontja alapján az illetékes hatóságok (önkormányzat, állam) megállapodása alapján van lehetőség.
A helyi személyszállítási feladatok átruházására a nemzeti vagyonról szóló 2011. évi CXCVI. törvény (Nvt.) rendelkezik. Ugyanis a helyi önkormányzat kizárólagos gazdasági tevékenységének körébe tartozik a menetrend szerinti helyi személyszállítási szolgáltatás, és e tevékenység gyakorlásának jogát a 12. $\$$ (12) bekezdése alapján az önkormányzat az állam részére átengedheti. $\mathrm{E}$ megoldás alapján a személyszállítási közszolgáltatások megrendelésében érintett két illetékes hatóság - a Magyar Állam a helyközi és az illetékes önkormányzat a helyi személyszállítási közszolgáltatások tekintetében - együttesen lenne jogosult a teljes helyi és helyközi (elővárosi, regionális, országos) szolgáltatási volumen megrendelésére. Ebben az esetben háromoldalú közszolgáltatási szerződés jönne létre, amely lehetővé tenné a közös finanszírozást is.

\section{KITEKINTÉS A KÖZÖSSÉGI KÖZ- LEKEDÉSI PIACRA LÉPÉS JOGI FELTÉTELRENDSZERÉRE}

A szolgáltatások szabályozási rendszerét alapvetően befolyásolja, hogy milyen szerepe van a személyszállítási szolgáltatások megszervezésében a felelős hatóságoknak. A szolgáltatások 
szervezése során két fő kategória különíthető el: a hatósági kezdeményezés és a piaci kezdeményezés.

A hatósági kezdeményezés lehetősége sok esetben a tulajdonviszonyokból (saját, köztulajdon) fakad, de az is gyakori, hogy a szolgáltatási követelmények tudatában a hatóság a tendereztetési rendszer alapján választja ki a piacról a legkedvezőbb szolgáltatót. Ebben az esetben a nyertessel szolgáltatási szerződést kötnek. Piaci kezdeményezés esetén nincs versenyeztetés, hanem a hatóság és a kezdeményező szolgáltató közötti tárgyalás alapján a hatóság által kiadott engedély formájában rögzítik a viszonyt, amely kizárólagos jogosultságokat jelent meghatározott időszakra és adott szolgáltatási területre vonatkozóan. A szolgáltatói kezdeményezések másik alcsoportját a szabad piacra lépés jelenti, ahol a szolgáltató - bizonyos tevékenység elvégzéséhez szükséges feltételek megléte esetén bárhol és bármilyen időtávon belül végezhet szolgáltatást.

A nemzetközi tapasztalatok alapján a szervezési formák közül a regionális és nagytávolságú (országos) autóbusz-közlekedési szolgáltatások esetén a piaci kezdeményezés a gyakori, míg a tipikusan kevésbé nyereségesen üzemeltethető városi és az elővárosi járatok esetében a hatósági kezdeményezés.

A közforgalmú autóbuszos személyszállítási modellek három típusba sorolhatók:

- Tendereztetés nélküli, kvázi monopolista modell, amelyben a koncesszió/engedély nem versenyeztetéssel nyerhető el, és a kizárólagos jogosultság legtöbbször a korábbi szolgáltatót illeti.

- Szabályozott versenymodell, ahol tendereztetési eljárás keretében választják ki az adott ellátási terület szolgáltatóját, akivel a megrendelő hatóság ezt követően közszolgáltatási szerződést köt.

- Versenymodell, ahol a dereguláció következtében nincs koncesszió, mivel a piacra lépés teljesen szabad.

A szolgáltatókkal kötött szerződéseknek tartalmaznia kell az alábbiakat:
- „az egyes ellátásért felelősök finanszírozási kötelezettségének rögzítését,

- a szolgáltatás színvonalával kapcsolatos elöírások közös meghatározását,

- az esetleges fejlesztések integrált, a település és az agglomeráció érdekeinek leginkább megfelelő megvalósítását,

- a tarifa-meghatározások során minden érdekelt szempontjainak figyelembevételét,

- a bevételek szedésének, megosztásának rendszerszintű kezelését,

- az egységes jegy- és bérletrendszer fejlesztését majd fenntartását,

- az elektronikus rendszerek (utastájékoztatás, e-ticketing) közös müködtethetöségét." [1]

\section{KÖZLEKEDÉSI SZÖVETSÉGEK}

Közlekedési Szövetségek, közlekedési társulások Európában számos helyen, rendszerint 1960 és 2000 között alakultak meg, ami összeköthető a motorizációs fejlődéssel. Létrehozásukat mindenütt politikai döntés elözte meg, megalakulásuk általában több lépcsőben történt, számos esetben a több mint 30 éve üzemelö rendszer ma is eredményesen müködik. E szövetségek önfejlesztő képességük következtében egyre jobban elérik az infrastruktúra, a járműpark, a jegyrendszer stb. fejlesztését és teljes körüvé tételét, korszerüsítését, működésük mérséklő hatást gyakorol a személygépkocsi használatra.

Az európai közforgalmú közlekedési rendszerek gyakorlatában két különböző típusú közlekedési szövetségi modell található.

- Felelös testületek szövetsége: helyi önkormányzatok, járások, régiók, állam stb. szövetsége. Akkor szükséges, ha a szolgáltatások finanszírozása a bevételekből (viteldíj, szociálpolitikai menetdíj-támogatás (SZMT) stb.) nem oldható meg. E modell fó problémája az, hogy a testületek hajlamosak szerepükön túlterjeszkedni. Ez az eset áll fenn, ha a szövetségben részt vállaló testületek egyben az üzemeltetöknek tulajdonosai is. Ilyen esetekben a vállalatoktól való távolságtartás nehezen biztosítható. 
- Üzemeltetők szövetsége: akkor lehetséges, ha a szolgáltatások nyújtása önfinanszírozó, de tevékenységük nem eredményez optimális szolgáltatásokat és az utasok megtartása érdekében szövetkeznek. E modell hátránya, hogy hosszú távon kartell képződhet, és valójában az üzemeltetők közös érdekeit védi, így önmagában nem vezet termelékenység- és hatékonyságjavuláshoz.

A városok és vonzáskörzeteinek ellátására olyan modellt kell választani, ami igazodik a terület jellemzőihez, a müszaki adottságokhoz, gazdasági helyzethez, jogi szabályozáshoz. Âltalában minden közlekedési szövetségben közös a fö funkciók koordinálása. A közlekedési szövetségben a három jellemző résztvevő szervezet típusa:

- a közlekedésért felelős hatóságok, ami a helyi, regionális, ill. a központi kormányzatot képviseli,

- a közlekedési szövetség,

- az üzemeltetők.

A megrendelői intézményrendszer hatósági jellegü. A közösségi személyszállítási közszolgáltatások ellátása a vonatkozó szabályozások (PSO, Sztv., Mötv) állami (helyi közlekedés esetében önkormányzati) hatósági kötelezettség. A fentiek alapján a közszolgáltatási szerződések megrendelöi intézményrendszere alapvetően attól függ, hogy melyik állami vagy önkormányzati szerv feladata az adott személyszállítási közszolgáltatás végzése, végeztetése.

\section{MEGRENDELŐ HATÓSÁG (ILLE- TÉKES HATÓSÁG VAGY HATÓ- SÁGCSOPORT)}

Megrendelöi minőségben járhat el valamenynyi illetékes hatóság, amely valamely tagállam vagy tagállamok bármely hatósága vagy hatóságcsoportja, amely egy adott földrajzi területen hatáskörrel rendelkezik a személyszállítás területén való beavatkozásra, vagy ilyen hatáskörrel felruházott bármely szerv. A fenti definícióból levezethető, hogy olyan állami (vagy több Európai Uniós tagállam hatásköre alatt álló) hatóságokról van szó, amely hatóságok jogosultak az illetékességi területükön személyszállítási közszolgáltatást közvetlenül odaítélni vagy pályázatra kiírni.

Az európai szabályozás nem zárja ki, hogy a tagállamok létrehozzanak olyan akár állami, akár önkormányzati többségi befolyás alatt álló szerveket, amelyeknek az állami, ill. az önkormányzati hatáskörbe tartozó közszolgáltatási kötelezettségeket adnak át, a feladat ellátásához szükséges forrásokkal együtt. Ez azt jelenti, hogy az illetékes hatóság a szükséges forrásokkal együtt átadja a teljes közszolgáltatási kötelezettséget a létrehozott különálló jogi személyiséggel rendelkező közlekedésszervezőnek. A közlekedésszervező a működése során ellátja az illetékes hatóság feladatkörébe tartozó közlekedési közszolgáltatásokkal kapcsolatos feladatokat (pályázatokat ír ki, közszolgáltatási szerződéseket köt, stb.) az adott illetékes hatóság ellenőrzése alatt. A közlekedésszervező feletti irányítás, ill. illetőségi területe attól függ, hogy az adott közlekedésszervezőt milyen hatóság és milyen illetőségi területre hozta létre. Hazánkban a lehetséges integrált közlekedésszervezési rendszerek felépítése az alábbi:

- Az állam, a megyeszékhely (föváros) önkormányzatai, de olyan városok is, ahol helyi közösségi közlekedés müködik, külön-külön elhatározhatják, hogy integrált közlekedésszervezési rendszert (hatóságcsoportot) alakítanak ki. Hatáskör: meghatározott állami ellátási felelösi terület (pl. előváros) és városi közigazgatási terület.

- A megye egész területére alakítanak ki hatósági jogkört, ehhez csatlakozni kell minden városnak, amelyek helyi közlekedést müködtetnek.

- Az állam és több megye városai közösen hoznak létre hatóságcsoportot (közlekedésszervezőt).

- Integrált közlekedésszervező létrejöhet egy-egy országrészre is. (Pl. az állam több megye területén, valamint azok városai, ahol van helyi közlekedés, hatóságcsoportot, majd közlekedésszervezőt hoznak létre (pl. Kelet-Magyarország). 
Végeredményben a jelenlegi szabályozás szerint létrejöhet bármilyen hatóságcsoport, így közlekedésszervező is, amelynek hatásköre nem országos.

A közforgalmú közlekedés európai alapszabályozását az 1370/2007/EK rendelet (továbbiakban: PSO-rendelet) tartalmazza. Az 5. cikkének (2) bekezdése szerint bármely illetékes helyi hatóság határozhat úgy, hogy közvetlenül ítél oda közszolgáltatási szerződéseket olyan elkülönült jogi egységnek, amely felett az illetékes helyi hatóság - illetve hatóságcsoport esetén legalább egy illetékes helyi hatóság meghatározó befolyást gyakorol. Az illetékes helyi hatóság fogalmát az EK rendelet 2 . cikk c.) pontja definiálja akként, hogy az bármely illetékes hatóság, amelynek földrajzi illetékessége nem országos.

A helyközi (országos, regionális, elővárosi) személyszállítási közszolgáltatások megrendelését a személyszállítási szolgáltatásokról szóló 2012. évi XLI. törvény 4 . $\$$-a alapján állami feladatként az ITM látja el, amelynek földrajzi illetékessége országos, helyi hatóságnak nem minősíthető. Ebből kifolyólag jelenleg belső szolgáltató kijelölésére nem jogosult, és az Alaptörvényben lefektetett állami intézményrendszeri keretek miatt illetékessége nem is redukálható az ország meghatározott részére.

A fenti fö szabályozási irány alóli kivételként az EK rendelet 5. cikkének (2) bekezdés d.) pontja alapján nem helyi illetékes hatóság is jelölhet ki belső szolgáltatót, ennek azonban kettős feltételrendszere van:

- nincs illetékes helyi hatóság, és

- a megrendelés egy adott földrajzi területre vonatkozik, amely nem országos.

E feltételekből a helyi személyszállítási közszolgáltatások és az országos személyszállítási közszolgáltatások egyértelműen kizárhatók (az előbbi azért, mert a települési önkormányzatok minősülnek helyi illetékes hatóságnak, az utóbbi pedig az országos jelleg miatt).

\section{LEHETSÉGES HAZAI PIACRA LÉPÉSI MODELLEK}

Magyarországon országos, elővárosi és regionális autóbuszos közszolgáltatást végző, a Volán társaságok fúziójából alakult hat regionális Közlekedési Központ és a Volánbusz Zrt. közszolgáltatási szerződése 2019. december 31-én lejár. Az új közszolgáltatók versenyeztetési alapon történő kiválasztását a PSO rendelet és a személyszállítási szolgáltatásokról szóló 2012. évi XLI. törvény (továbbiakban: Sztv.) elöírásai szerint hajthatja végre az arra illetékes minisztérium (ITM). Az intézményi, szervezeti modellek kialakítása szerint az alábbi feladatok ismertek:

- a közlekedési közszolgáltatásért felelős rendszer újragondolása, szervezeti átalakítása,

- felelősségi rendszerek és feladatkörök pontosabb meghatározása (megrendelői intézményrendszer pályáztatás vagy közvetlen piaci odaítélés kapcsán),

- folyamatok mentén a funkciók újragondolása, új funkciók kialakítása, szükség szerint megrendelői és operátori integrálása,

- államháztartásra gyakorolt hatásának vizsgálata,

- igény alapú közlekedés fejlesztése szolgáltatásfejlesztésekkel,

- az alágazatok együttmüködésének azonosítása (közszolgáltatások és közlekedési módok összehangolása)

- társadalmi mobilitási igények teljesítése, a szolgáltatás minőségi elvárásainak meghatározása,

- tendereztetés (pályáztatás), valamint közvetlen odaítélés jogi megalapozottsága, szolgáltatási területek kialakítása;

- hazai állami operátorok közvetett céljának megvalósításához segítségnyújtás, hogy közszolgáltatási pályázatokon eredményesen vehessenek részt,

- versenyképességi és hatékonysági kritériumok megfogalmazása.

A lehetséges piacra lépési intézményi modellek az alábbiak:

- A Versenyeztetés modell lényege, hogy az operátorok közúti közlekedési köz- 
szolgáltatáshoz szolgáltatási csomagokra bontva (hálózat, vonal, vonalcsoport stb.) valós versenyeztetéssel jutnak hozzá.

- A Közvetlen odaítélés modell esetén a hatáskörrel és illetékességgel rendelkező hatóság területén a szolgáltatásokat közvetlenül rendeli meg az adott operátortól, aki felett ún. döntő befolyást gyakorol a megrendelést és végrehajtást illetően. A hatásköri területre nem azonosítható járatokat, (transzrégiós és országos járatok) odaítéléssel nem lehet szervezni, ez esetekben is kötelező a versenyeztetés.

A két intézményi modell (a közvetlen odaítélés és a versenyeztetés) jó néhány elemében megegyezik, ugyanakkor jelentős eltéréseket is tartalmaz.

Mindkét változatra egyaránt vonatkozik:

- Ellátandó szolgáltatási csomagok és szolgáltatási színvonal azonos elvárású meghatározása.

- 10 évre vagy annál rövidebb időre való elkötelezettség a piac ellátása szempontjából, ahol mind a kötelezettségeket mind pedig a meghirdetett feltételeket biztosítani kell a hatóságnak (megrendelőnek).

A közlekedési közszolgáltatás tárgyának mennyiségi meghatározása a szolgáltatási csomagok, míg minőségi meghatározása a szolgáltatási színvonal meghatározását jelenti.

- Versenyeztetés modell esetén a pályázati kiírásban megjelenő és a közszolgáltatási szerződés hatálya alá tartozó területi lehatárolást jelentik a szolgáltatási csomagokat.

- Közvetlen odaítélés modell esetén a decentralizált hatóság hatásköri és illetékességi körébe tartozó térséget jelenti, ahol a döntő befolyás mellett az operátor csak szigorú kritériumok alapján végezhet a közvetlen odaítéléshez kapcsolható közszolgáltatást.

A kormány egyértelmü közlekedéspolitikai szándéka a helyközi vasúti és autóbusz, valamint a helyi és az elővárosi közlekedési rendszerek szolgáltatási, intézményrendszeri és ellátási összehangolása. Hiteles értékelés még nem történt az elmúlt öt évben arról, hogy ennek elősegítésében mekkora előrelépést jelentett a 24 autóbusz-közlekedési társaság hét nagy szolgáltatóba történő átszervezése. A MÁV csoport egyfajta konszolidációja megtörtént, és a budapesti agglomerációt kiszolgáló HÉV és autóbuszvonalak megrendelése átvételre került az állam részéről.

A jelenlegi helyközi autóbuszközlekedési közszolgáltatást végző hét állami és négy magántársaság szerződése 2019. december 31-én lejár. Jogi értelemben már nincs lehetőség a szerződések meghosszabbítására, csak egy eredménytelen pályázat esetén átmenetileg ún. szükséghelyzeti intézkedés vezethető be, úgy hogy a közszolgáltatás társadalmi érdekből fennmaradjon.

$\mathrm{Az}$ a döntés már megszületett, hogy a teljes jelenlegi hazai helyközi autóbusz-hálózat üzemeltetése meghirdetésre kerül, a közlekedési régiónként kialakított területi elvü hét nagyhálózatra és hét kishálózatra.

- A kishálózati rendszer területi azonosítása megtörtént közlekedési régiónként a teljes menetrendi km legfeljebb 4-5\%ában.

- A nagyhálózatokat a jelenlegi közlekedési régiók területén alakítják ki, amelyek a jelenlegi kibocsátott menetrendi kilométerek 95-96\%-át jelentik.

A pályázati csomagok feltételrendszere, szakmai kialakítása jelenleg folyik. A tender kidolgozásával természetesen a jelenlegi hazai operátorok (Volánok és hazai kkv-k) eséllyel pályázhatnak a feladatokra. Az előzetes tájékoztatók a TED-en már 2018 decemberében megjelentek.

\section{SZABADPIACI MEGOLDÁSOK}

Magyarországon jelenleg a menetrend szerinti személyszállítási szolgáltatások szinte teljes egészében közszolgáltatási szerződés alapján, közfinanszírozással biztosítottak, leszámítva például a városnéző autóbuszokat, a nosztalgiavonatokat és az egyéb, marginális jelentőségű teljesítményeket. Más országok- 


\section{Közösségi közlekedés}

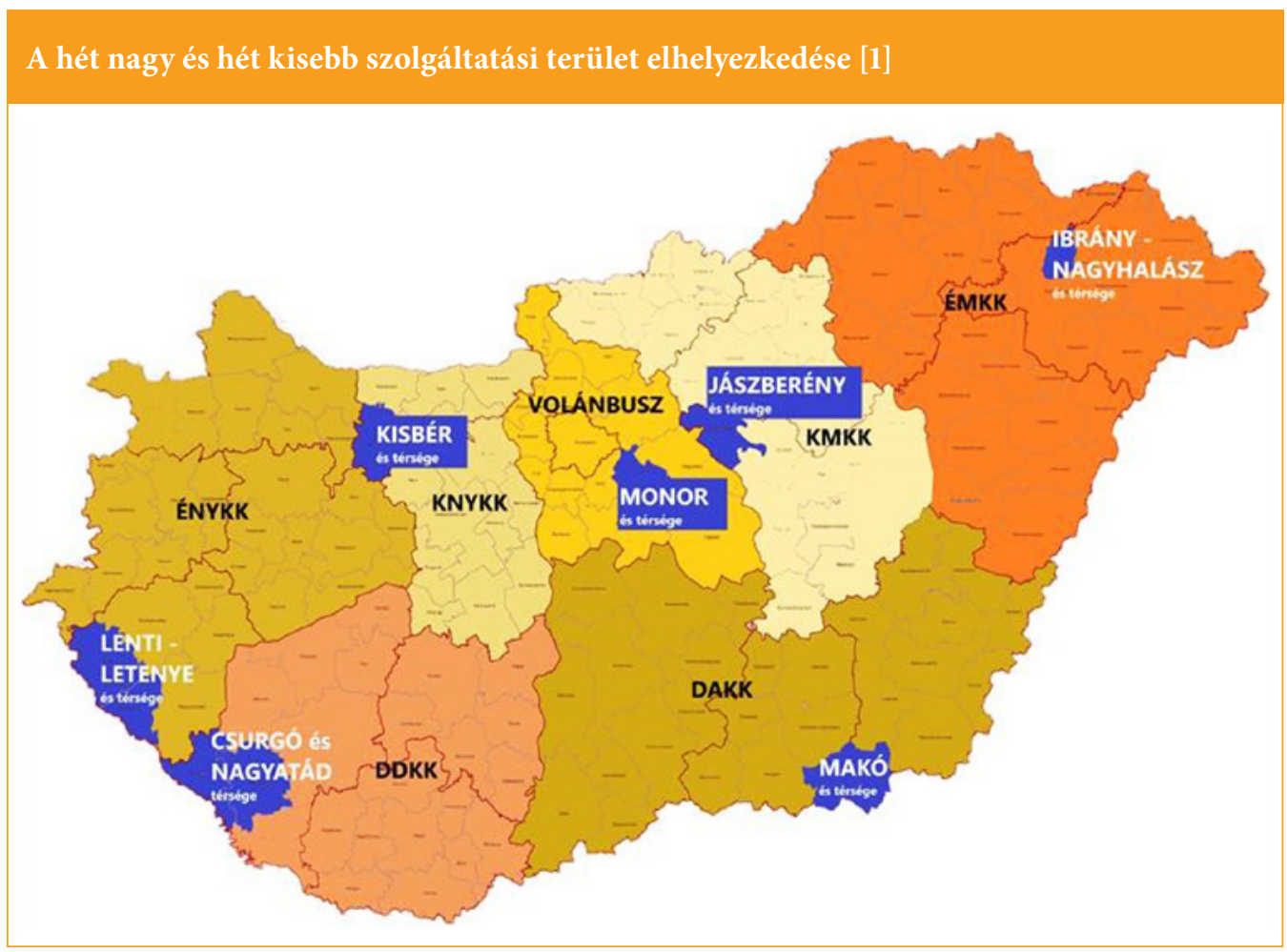

ban ennél lényegesen nagyobb a piaci/üzleti/ kereskedelmi alapon működtetett személyszállítási szolgáltatások aránya [8]. Jellemzően a távolsági személyszállítás piaca a liberalizált és deregulált, Magyarországon viszont olyannyira „fogalmunk sincs” a liberalizált személyszállításról, hogy szó szerint definíciós deficit érezhető: nincsenek erre a tevékenységre a szakma által széles körben elfogadott fogalmaink, meghatározásaink sem. Sajnos a releváns EU-s anyagokban sem teljesen konzekvens a piacnyitás, a liberalizáció, a dereguláció és a hasonló jelentésű kifejezések használata.

A hazai piaci alapú személyszállítás lehetőségével már a 2016-os Győri Közlekedéstudományi Konferencián foglalkozott egy előadás és egy kapcsolódó cikk [2], azóta a helyzet lényegesen nem változott, de a fö gondolatokat érdemes felidézni.

A közelgő autóbuszos piacnyitás nem fogja azt jelenteni, hogy „bárki bárhova bármikor” indíthat autóbuszjáratot. A $7+7$ régióban a verseny nem elsősorban az utasokért, hanem a szolgáltatás jogáért indul, valamint az ehhez kapcsolódó költségtérítésért, ami a szolgáltatók számára a bevételekkel nem fedezett indokolt költségek megtérítését jelenti.

Gyakran felmerül, hogy a hazai helyközi személyszállítás piacán is szükséges vagy érdemes lenne - legalább egyes szegmensekben vagy vonalakon - egy másfajta, liberalizált üzleti modell müködését lehetővé tenni. Bőven van ilyenre példa Európán belül és azon kívül is, de az autóbusz-közlekedés eltérő működési modelljeit illetően leginkább az Egyesült Királyságot és Németországot, valamint Svájcot szokás emlegetni. Ezek a példák azonban meglehetősen szélsőségesek, és nem adaptálhatóak Magyarországra, ugyanakkor számos tanulsággal szolgálnak.

Liberalizáció terén az Egyesült Királyság volt az élenjáró, ahol már a 80-as években lezajlott a folyamat, vegyes eredményekkel [3]. 
Fontos kiemelni, hogy ott egy már meglévő hálózat deregulációjáról volt szó, ellentétben a 2013-as német, a 2015-ös francia és 2017es svájci liberalizációval, ahol egy korábban gyakorlatilag nem létező piac megnyitása történt meg. Mindhárom utóbbi országban voltak aggodalmak a távolsági autóbuszos liberalizáció vasúti utasforgalomra és egyéb közszolgáltatási rendszerekre való negatív hatását illetően, de ezek nem bizonyultak megalapozottnak.

Németországban 5 év alatt bő 20 millió utast szállító piaccá nőtt a távolsági autóbusz-közlekedés, és eközben a vasút meg tudta őrizni a piaci pozícióit, az autóbusz-közlekedés tehát főleg új utasokat tudott megszólítani [7]. Hasonló volt a helyzet Norvégiában is [4]. A szolgáltatók közötti kezdetben élénk verseny 3-4 év alatt monopolisztikussá vált, a piac mintegy $90 \%$-át uraló Flixbus működése pedig leginkább egy közlekedésszervezőre hasonlít. Az Egyesült Királyságban a National Express hasonló szereppel bír: maga nem üzemeltet járatokat, hanem alvállalkozókat von be e célból, és egységes márkanév alatt szervezi és értékesíti a szolgáltatást. Svájcban is megtört a jég, és az alpesi országban is felismerték, hogy a közlekedési rendszer fenntarthatóságát nem a belföldi távolsági autóbusz-hálózattól kell félteni, hanem épp ellenkezőleg, ez a közlekedési mód nyújthat lassabb, de megfizethető árú eljutási lehetőséget az eseti, árérzékeny utasoknak. Ennek jegyében megkezdődött a belföldi távolsági autóbusz-hálózat fejlesztése, de a folyamat még gyerekcipőben jár. Franciaországban is a kezdeti fellángolások után fúziók történtek, az államvasút saját autóbuszos vállalkozással szállt be a liberalizált piacra, amit 2018. év végén adott át a sharing economy elvén működő BlaBlaCarnak - ezzel is mutatva, hogy a vasút, az autóbusz és a telekocsi mind az egyéni közlekedés kihívója is, és akár egymást is ki tudja egészíteni.

Közös a fenti példákban, hogy a távolsági autóbusz-közlekedés liberalizációjának fö céljai teljesültek: a jegyárak csökkentek, a mobilitási lehetőségek növekedtek, és élénkült a gazdasági aktivitás, ugyanakkor az idealisztikus többszereplős verseny jellemzően nem alakult ki, vagy nem maradt fenn tartósan. A liberalizált piacokon a szereplők egymás pozícióit többnyire tiszteletben tartják, nem bocsátkoznak felesleges versenybe, föleg nem árversenybe. Kialakult egy újfajta optimum, ami az egyéni közlekedéssel szemben versenyképesebb személyszállítási szolgáltatásokat jelent.

Hazánkban a távolsági közlekedés liberalizációját több szempontból is nehéz elképzelni. Egyrészt a hazai autóbusz-közlekedésben a távolsági járatok zömén az utasok főleg rövid távolságokra utaznak, és e járatok integrálva vannak a regionális közszolgáltatásba. Másrészt, a teljes árú jegyek árfekvése közepesnek mondható, ugyanakkor nagyon kiterjedt szociálpolitikai kedvezményrendszer működik, így ezekkel piaci alapon versenyezni nem tünik reálisnak, amennyiben a piaci alapú szolgáltatók nem jogosultak SZMT-re. Harmadrészt, a munkába járás költségtérítése igen magas (86\%), és ez inkább a sürü közszolgáltatás terén biztosít nagy mobilitási szabadságfokot, semmint az ezzel esetlegesen néhány járattal versenyre kelő piaci alapú járatok számára. Negyedrészt, a hálózati lefedettség kiválónak tekinthető, Budapest és a nagyobb városok közötti vonalakon sürü, ütemes menetrend szerint közlekednek az autóbuszok és a vonatok, viszonylag alacsony utasszámmal. Nem igazán létezik olyan nagy volumenü utazási igény, amit a közforgalmú közlekedés menetrendje nem tudna kielégíteni, emiatt tehát a piacra belépésre alig van alkalmas rés. Ötödrészt a hazai közlekedéspolitika a vasút priorizálását tűzte zászlajára, és ez nem közgazdasági kérdés. Ugyanakkor a személyszállítási közszolgáltatásokra fordítható források végesek, ezért e téren leginkább a közszolgáltatások piaci alapú szolgáltatásokkal való jól szervezett kiváltása jöhet szóba. Ebben az esetben a közszolgáltatás rendszerébe való integráltság kérdéskörét (pl. bérletelfogadás, finanszírozás) kell tisztázni, valamint szükséges az is, hogy a piacra belépő szolgáltatók hosszabb távon kiszámítható feltételekkel tervezhessenek. 


\section{KONKLÚZIÓ}

A helyközi autóbuszos közszolgáltatási szerződések alapján 2019. december 31-ig biztosított az országos, regionális és elővárosi autóbuszos személyszállítási közszolgáltatás. Az ezt követő időszakra a szolgáltatók kiválasztására számos eljárás és modell létezik, ezeket mutatja be röviden a cikk. Egyelöre az várható, hogy - összhangban a jelenlegi közlekedési régiók elhelyezkedésével - 7+7 szolgáltatási csomag kerül tendereztetésre. A hét nagyobb csomag ellátása több száz autóbuszt igényel, így elsősorban nagyobb operátorok számára lehet vonzó, de minden közlekedési régióban meghirdetésre kerülnek kisebb csomagok, melyek már kkv-k számára is elérhetőek. A kormányzat szándéka az, hogy az autóbuszos és vasúti alágazat sokkal erősebben működjön együtt, és ehhez szükség van a megrendelői szerep erősítésére, akár az intézményrendszer módosítására is. Ennek lehetőségeit is vázolja a cikk, amely az előzetes tájékoztató előkészítési folyamatában lefolytatott szakértői egyeztetéseken, mühelybeszélgetéseken elhangzott információkon, jogi szakértői véleményeken és a közremüködő szervezetekkel elkészített részanyagokon alapul. A belföldi távolsági autóbusz-közlekedés liberalizációjának, deregulációjának témaköréből levont fő következtetés az, hogy Magyarországon ez még elképzelés szintjén is gyerekcipőben jár, holott lenne létjogosultsága egy ilyen üzleti modellnek, de - tekintettel a már most is kínálati jellegű távolsági vasúti és autóbusz kínálatra - nem a jelenlegi közszolgáltatáson felül, hanem akár annak részelemeit kiváltva.

\section{FELHASZNÁLT IRODALOM}

[1] Dr. Szeri István KTI és Ifua munkacsoport „a helyközi közösségi közlekedés ellátási felelősi döntéseket megalapozó stratégiai feladatokról", Munkaanyag az ITM részére, 2018.

[2] Ács B.: A személyszállítási piacnyitás tapasztalatai és lehetőségei, In: Dr. Horváth, Balázs; Horváth, Gábor; Gaál, Bertalan (szerk.) Közlekedéstudományi Konferencia Györ 2016, pp. 162-175. Györ, Magyarország: Széchenyi István Egyetem, (2016) p. 429

[3] White, P. - Robbins, D.: Long-term development of express coach services in Britain. Research in Transportation Economics, 2012/36, 30-38.

[4] Aarhaug, J. - Fearnley N.: Deregulation of the Norwegian long distance express coach market. Transport Policy, 2016, 46: pp. 1-6.

[5] http://www.kormany.hu/download /b/84/10000/Nemzeti_Közlekedési_Infrastruktúra-fejlesztési_Stratégia.pdf (2019.2.15)

[6] https://eur-lex.europa.eu/legal-content/HU/ TXT/PDF/?uri=CELEX:52011DC0144\&fro $\mathrm{m}=\mathrm{LV}(2019.2 .15)$

[7] http://www.svz.de/regionales/mecklenburgvorpommern/verkehr/viele-steigen-vonauto-auf-fernbus-um-id8802896.ht ml (2019.1.15)

[8] https://ec.europa.eu/transport/sites/ transport/files/modes/road/studies/ doc/2016-04-passenger-transport-bycoach-in-europe.pdf (2019.1.15)

\title{
E számunk lektorai
}

\author{
Dr. Katona András - Dr. Nagy Vince
}

Dr. Péterfalvi József Dr. Tóth János Dr. Tóth László 


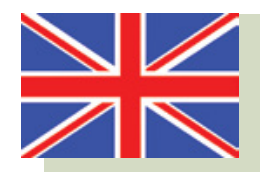

The domestic possibilities of institutional market access rules for public transport

Public service for national, regional and suburban bus services will be provided until 31 December 2019, based on the current inter-city bus service contracts. There are a number of procedures and models for selecting the service providers for the following period. These are briefly described in the article. For the time being, it is expected that $7+7$ service packages will be tendered in line with the location of the current transport regions. The servicing of the seven major packages requires several hundred buses, making it more attractive to larger operators. Smaller packages, however, are also available in all transport regions; these can be available also for SMEs. The intention of the government is that the bus and railway sub-sectors work together much more strongly, and this requires the strengthening of the role of the customer as well as the modification of the institutional system.

\section{Die inländischen Mög- lichkeiten in der Rege- lung des institutionellen Marktzugangs für den öffentlichen Verkehr}

Der öffentliche Dienst in der Personenbeförderung im nationalen, regionalen und Vorortverkehr ist bis zum 31. Dezember 2019 auf der Grundlage von Überlandbusverträgen gesichert. Es gibt eine Reihe von Verfahren und Modellen für die Auswahl der Dienstanbieter für den nachfolgenden Zeitraum, die im Artikel kurz beschrieben werden. Zur Zeit es wird erwartet, dass - im Einklang mit den Standorten der aktuellen Verkehrsregionen - $7+7$ Dienstleistungspakete ausgeschrieben werden. Die Versorgung von den sieben Hauptpaketen erfordert Hunderte von Bussen, was für größere Betreiber attraktiv werden kann. Kleinere Pakete werden jedoch in allen Verkehrsregionen ausgeschrieben erhältlich, die auch für KMU zugänglich sind. Die Regierung beabsichtigt, dass die Teilsektoren Bus und Bahn viel enger zusammenarbeiten, und dies erfordert die Stärkung der Rolle des Auftraggebers sowie möglicherweise auch die Änderung des institutionellen Systems.

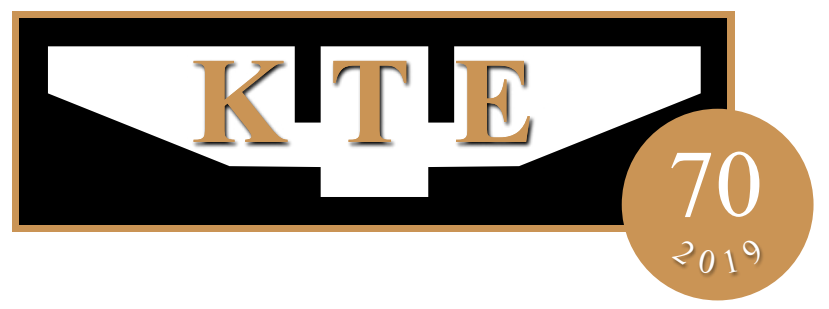

